\title{
EFL Oral Communication Teaching Practices: A Close Look at University Teachers and A2 Students' Perspectives in Thailand and a Critical Eye from Serbia
}

\author{
David Allen Bruner ${ }^{1}$, Kemtong Sinwongsuwat ${ }^{1} \&$ Biljana Radić-Bojanić ${ }^{2}$ \\ ${ }^{1}$ Faculty of Liberal Arts, Prince of Songkla University, Thailand \\ ${ }^{2}$ Faculty of Philosophy, University of Novi Sad, Serbia \\ Correspondence: Asst. Prof. Kemtong Sinwongsuwat, Ph.D., Department of Languages and Linguistics, Faculty \\ of Liberal Arts, Prince of Songkla University, Hat Yai, Songkhla 90112, Thailand. Tel: 1-66-074-28-6771. E-mail: \\ ksinwong@gmail.com
}

\author{
Received: September 16, 2014 Accepted: October 18, 2014 Online Published: December 17, 2014 \\ doi:10.5539/elt.v8n1p11 URL: http://dx.doi.org/10.5539/elt.v8n1p11
}

\begin{abstract}
This paper aimed to reexamine current EFL oral communication teaching practices from the perspectives of teachers and A2 students at two universities, namely Prince of Songkla University (PSU), Thailand and University of Novi Sad (UNS), Serbia. The main objectives were: (1) to analyze current practices from the perspectives of teachers and students, (2) to identify real problems encountered by teachers and students attempting to embrace Communicative Language Teaching (CLT) to improve oral English communication, and (3) propose practical solutions for classroom practices to improve the majority of students' oral proficiency from the elementary level.

The findings were that oral English communication classes at PSU continue to embrace CLT and that the majority of Thai A2 students were frequently engaged in group activities rather than in individual and teacher-centered tasks. There was reliance on unrealistic, scripted role plays. Unlike the Serbian students, Thai students apparently needed to acquire more independent skills, become less passive learners, and interact more spontaneously in the target language. Other problems at PSU included mixed ability classes. Recommendations are placement tests, choices of more advanced elective courses, rigorous enforcement of upper enrollment limit, a balance between group and individual communicative tasks, and replacement of scripted with non-scripted role plays.
\end{abstract}

Keywords: communicative language teaching, EFL university students, non-scripted role plays, oral English communication, Serbia, teaching and learning practices, Thailand

\section{Introduction}

With globalization, and the phenomenal acendency of English as a lingua franca both domestically and internationally, the importance of English language acquisition is undiniable. Today in many countries, particulary in the "Expanding Circle" (Kachru, 1985), where English has earned the role of the main language of international communication, increasingly it is also used for intra-national purposes. Foley (2005, as cited in Baker, 2009) asserted that English, for example, is the de facto second language of Thailand, blurring the distinction between Kachru's Expanding and Outer Circle, being compulsory at all educational levels, whether formal or informal. It is the language of academic advancement, social and economic growth, tourism industry, science and technology, the Internet, international businesses, and international legal contexts. The use of English has evolved from just an essential foreign language to a world language for external and internal purposes. In the educational context, formally or informally learning English at the outset of one's educational career is essential. With globalization, countries in both the East and the West are endeavouring to form economic unions in order to compete, demanding an investment in human resources so that they are equipped with essential English language skills.

In fact, CEOs of major companies in rapidly expanding economies in Asia require their workers to have adequate English abilities in order to be an asset to the company and allow it to benifit from increased foreign investment (Byrne, 2010). English plays a pivotal role in policies promoting free trade and economic cooperation 
in both Asia and Europe. For instance, in response to the drafting of the ASEAN charter in 2008 in an attempt to solidify and integrate the ASEAN community into one seamless economy, many companies have adopted recruitment policies requiring employees to have essential English language skills for the workplace. Likewise, with the prospect of future integration of the Balkan countries into the European Union, having workers with good English communicative skills has become a priority. The feasible goal in English language teaching and learning today appears to be to master the language such that international intelligibility is guaranteed while expressing and maintaining one's local or national identity (Crystal, 2003).

Admist these changes, it is now critical for English language educators to reevaluate the effectiveness of current English language teaching to determine whether the current practices are producing students who can communicate effectively in the international context, particularly ones who can effectively meet communicative demands of any speech events in international contexts. A close look at the oral communication classroom has become even more indispensible especially when Thai students' average English proficiency was often proven the lowest among (Southeast) Asian countries (Education First, 2012; Khamkhien, 2010; Prapphal, 2001; WhereisThailand.info, 2012).

Undoubtedly, the national education reform enforced by the National Education Reform Act of B. E. 2542 (1999) and now in its second phase (Government Public Relations Department, 2010; Laksanavisit, 2009; Sinhaneti, 2011) has instigated positive changes to English language teaching curricula inThailand (see e.g. Chanawongse, 2010; Wiriyachitra, n.d.). Over the course of her history, the country had in fact observed changes of English teaching practices from focusing on rote memorization, grammar and translation, reading aloud for pronunciation and comprehension, and teacher-centeredness to a more communicative, learner-centered approach (Darasawang, 2007). Communicative Language Teaching (CLT) has in fact become a major part of the reform launched by the government through the Act, as amended in 2001, alongside the embracement of learners' centeredness, diversity and local culture (Cheewakaroon, 2011; Darasawang, 2007).

Enforced particularly by the Basic Education Curriculum 2001, CLT has particularly changed the emphasis of teaching EFL at every level in the country to enabling students to use the language accurately and appropriately for communicative purposes (Saengboon, 2002). At the university level in Thailand, where every student is required to take two foundation English courses and at least two elective courses, learning strategies to acquire appropriate language competence are also considered of equal importance to learning to use the language in both academic and non-academic settings. The students are often engaged in task-based learning and encouraged to partake in independent learning in technology-rich environments offered by self-access learning centers across campus after class.

The National Educational Reform Act has undoubtedly made positive changes and provided a valuable roadmap for Thailand's 21 st century education at every level. But the problem remains in transforming the vision depicted by the roadmap into reality, given that the overall English proficiency of Thai university students remains low in comparison to students from other ASEAN countries and internationally. Despite successive governments' considerable financial investment, it is admitted that internationally Thailand still lags behind on many aspects of education and human resource development. Too much emphasis has apparently been placed on management and infrastructures, constructing buildings and acquiring new teaching and learning resources, rather than focusing on improving the quality of teaching, learning and creating innovative, knowledge-building research (cf. Fry, 2002; Government Public Relations Department, 2010).

Additionally, even though there have been increasing attempts towards internationalization at the university level, the English language competence of the majority of Thai university students remains low, undermining their ability to enjoy the benefits of internationalization. According to Prapphal (2001), the average English proficiency of Thai university students measured by TOEFL-equated CU-TEP scores was lower than students from most ASEAN countries. In fact, PSU's in-house English proficiency test, which was recently developed and administered to 3rd-year students across different campuses, also revealed the average English proficiency score of approximately 40\%, which is far from satisfactory (PSU Faculty Academic Board Meeting, 2011).

Moreover, the reform efforts put forth by educators and policy makers with regard to English language teaching and learning at the university level have so far been focused more on national proficiency test development, curriculum change, teacher training, management and utilization of ICT resources for teaching and independent learning. The implementation of the English education reform is still in its infancy stage, being limited mostly to policy enforcement. Taking a top-down approach, it has yet to directly address teaching and learning practices of language teachers and learners. Attention still needs to be paid especially to those classroom practices involved in the development of oral English communication skills which have been shown to be very problematic among 
the majority of Thai students but hardly assessed in the national tests being developed. It is now critical to get a grasp of learners' and practitioners' learning and teaching processes in particular teaching and learning contexts if Thailand's graduates are to be prepared to contribute to and reap the benefits of the vision of one unified ASEAN economic community planned to take effect in 2016.

The rationale of this study and therefore its three main objectives are: to look closely at the current actual practices in the oral English communication classroom from the perspectives of those in the classroom on a daily basis, namely teachers and students, to identify real problems encountered by teachers and students attempting to embrace communicative language teaching and task-based, learner-centered, independent learning policies; and in light of the problematic areas, to propose practical solutions to the classroom practices for improving the oral English proficiency of the majority of university low proficiency learners.

The perspectives shared in this paper are primarily based on teachers' experience, observations, and the findings from a questionnaire survey of the majority of Prince of Songkla University (PSU) and University of Novi Sad (UNS) undergraduate students taking oral English communication courses, as well as of the teachers teaching the classes during the Academic years 2011-2014 as partly reported in Bruner, Sinwongsuwat, and Shimray (2014). The majority of students whose views were reflected in this paper were at the Elementary (A2) level of the English proficiency determined by the Cambridge Quick Placement Test (CQPT) (University of Cambridge Local Examinations Syndicate, 2001). The Serbian participants referred to in the paper were Serbian teachers of oral English communication course and Serbian A2 undergraduates taking English language courses in the academic year 2012. It should be noted that while this paper is not a comparative study as such, references to results obtained from the perspectives of both Serbian teachers and students are used as a reference point against which the results from the perspectives of Thai teachers and students are assessed in order to highlight what may account for the higher proficiency of Serbian students in relation to their Thai counterparts. Despite being specific to local research settings, the findings on current practices in oral English communication classrooms, as well as problematic areas and recommendations proposed are applicable to teaching and learning in other EFL university settings.

\section{Methodological Comments}

As detailed in Bruner et al. (2014), the research venues were the Faculty of Liberal Arts (FLA), Prince of Songkla University (PSU)-Hat Yai, Thailand and the Faculty of Philosophy (FP), University of Novi Sad (UNS)-Serbia. The survey participants who were purposively sampled and whose views were reported in this paper included the majority of PSU and UNS undergraduate students enrolled in oral English communication courses where the focus was to develop oral English communication skills during academic years 2011 and 2012. Represented here were the views of 439 2nd-4th year students with the majority level of English proficiency, Elementary (A2), who were enrolled in the summer courses and administered the Cambridge Quick Placement Test (CQPT). The placement test was rerun in the summer semester of the following academic year with a new group of students and again the majority was at the A2 level. Accordingly the A2 group was chosen as the appropriate participants when analyzing the data from the survey questionnaire. The participants at UNS, Serbia, by contrast, were undergraduate students studying English in the 2012 academic year. The UNS participants also took the CQPT at the outset of that year and the majority was designated as the A2 level after their responses was analyzed. The teachers whose views are reported taught oral English communication courses at the respective universities at the time of the survey. The questionnaires given were designed to obtain a comprehensive look at oral English language teaching and learning from both students and teachers' perspectives; they were constructed based mainly on issues that are usually of concern to EFL language educators. The entire survey contained six relatively equally divided sections of concern. This paper discusses the two main sections dealing with teachers' and learners' perspectives regarding oral English communication teaching and learning. Therefore, apart from researchers' observations and experiences as oral English communication teachers, the discussion in this paper is in part based on PSU and UNS teachers' and students' responses to statements on the Likert scale and closed and open-ended questions in the constructed questionnaires. With respect to student responses to statements on the Likert interval scale (a range from strongly agreed (4.51-5.00) to strongly disagreed (1.00-1.50), statistical correlations and interval-scale analysis were undertaken. The information on the survey questionnaires used is provided in the appendix.

\section{Current Practices in the Oral English Communication Classroom from the Perspectives of University Teachers and Thai A2 Learners}

Based on the researchers' own observations and findings from the survey, oral English communication classes conducted at PSU, whether compulsory or elective, clearly continue to embrace Communicative Language 
Teaching (CLT). The syllabus, teaching materials, class activities, and requirements were oriented towards Whong (2011)'s key features of CLT, namely authentic input and interaction. The priority was given to the learners' ability to communicate fluently in diverse contexts, not merely the mastery of the structure of the language. The methodology of pattern drills or rote memorization has been replaced by meaning and use of language forms in meaningful communicative contexts, aiming at enabling them to acquire the target language and express what they need to express in real world communication. It was observable that the teachers at PSU in fact engaged the A2 students in meaningful activities, giving priority to fluency rather than merely focusing on accuracy. This was obviously facilitated by contemporary commercial books used in which only essential grammar points were presented and activities promoting listening and speaking were emphasized (Richards \& Bohlke, 2012; Stempleski \& Robertson, 2007). The teachers additionally tried to provide feedback that did not disrupt their students' talk, often along with their modeling or after the students finished speaking. The errors were mostly tolerated unless they caused communication breakdowns.

Additionally, since in CLT, the language focus is based on students' present and future needs, CLT-oriented textbooks chosen were assured of authentic materials and English as used in real life. It was found that just as at UNS in Serbia, commercial textbooks with authentic audio-visual materials along with workbooks and the Internet were used in the overwhelming majority of the oral communication classrooms to facilitate teaching. However, unlike the classes offered at UNS, in which integrated-skills textbooks were used, the oral communication classes at PSU primarily employed textbooks targeting individual skills, particularly speaking and listening. The main aim of the conversation class at PSU apparently was to provide authentic materials stimulating oral communication on topics in daily life situations. Reading-integrated textbooks as used at UNS to provide content that feeds oral discussions were perceived by Thai teachers to be too advanced for the Thai A2 students.

Apparently, for the Thai A2 students, basic conversation skill training was seen as essential before moving onto more advanced oral discussion skills in higher-level courses. This was also reflected by the teaching and assessing methods adopted in English speaking courses at PSU; the majority of Thai A2 students were more frequently engaged in group activities such as practicing model conversations and role-playing rather than listening to English lectures. Additionally, to fulfill course requirements, apart from in-class role-plays, students were also asked to take both mid-term and final exams in which vocabulary, grammar, basic listening and conversation skills were assessed. The Serbian students observed on the other hand were mostly engaged in listening to lectures, giving individual or group oral presentations, and taking reading-based final exams, which also test vocabulary and grammar.

In-class activities were regarded as equally important by teachers and students from both universities. Following CLT, collaborative activities were emphasized. The Thai teachers always relied on group work, followed by pair work. Given the typical class size of 30-40 students in Thailand, the students were mostly asked to form a smaller group of three to four and work together on a speaking exercise. With a smaller class size, approximately 20-30 students each, the Serbian partners on the other hand more frequently engaged their students in pair work and individual work. In both countries, the desks were often arranged in the same way in rows with gaps to facilitate individual and group work even though classroom seats at PSU, which were loosely structured, appeared to better able to accommodate collaborative work. The Thais reportedly favored group work but were least comfortable with volunteering and answering questions; they apparently needed to acquire skills to become more independent learners. The Serbian students on the contrary felt most comfortable with asking and answering questions but apparently disdained peer related activities such as peer feedback, group work and pair work.

The Thais reportedly attached the most significance to core-skill class activities but the least to wrap-up activities and clear instructions, while the Serbs found clear instructions and lesson goals as well as post-skill training or wrap-up activities most useful. For Thai students, it remains mostly in the classroom that they have the opportunity to be exposed to the target language; therefore, their reliance on classroom activities did not come as a surprise. In fact, in-class activities which allow them to communicate and work with their peers were also viewed as being the most useful and easiest to fulfill for the Thais.

The Thai students reportedly preferred to be assessed in groups by means of such activities as role-play the most. The role-play mostly employed in a Thai conversation classroom was often of the scripted type, which allowed them to prepare their script and rehearse the conversation according to the situation assigned in advance. Additionally, given no reading was emphasized in the majority of oral communication courses at PSU, individual tests such as reading comprehension were reportedly not preferred by the Thais, which was different from the Serbs, who favored final exams with reading comprehension, the assessment type they were most accustomed to. 
The teacher's role in a CLT classroom typically changes from primarily an information giver/care taker/lecturer/presenter to a facilitator/guide/motivator/director, and learners have become language users or explorers learning through doing or using the language and making a discovery. The Thai learners are required to be more active in their own learning. While teachers on both sides noticeably were classroom facilitators, the teachers at PSU apparently assumed more of the director's role, whereas those at UNS frequently gave a lecture, as reported by the students. The former frequently directed them into collaborative work, whereas the latter gave a lecture, taking the students through a structured lesson plan following the format of the textbook. Given apparently lower oral proficiency, the Thai A2 students were more passive, doing as instructed and hardly raising questions or offering voluntary responses. The Serbian A2 students' class interaction seemed to take place more spontaneously in the target language. The students were more prepared for class discussion stimulated by the course materials.

\section{Problematic Areas in an Oral English Communication Classroom and Recommended Solutions}

Through surveying the A2 majority of oral English communication students and their teachers at the two universities and through the researchers' experiences and observations, several problematic areas with the current classroom practices were identified. These include mixed ability classes, classes that have too many students, an overemphasis on pair and group work in Thailand resulting in an imbalance with individual tasks and the inability of Thai students to work independently. These problematic issues are likely to exist in other university EFL settings, particularly in Asia, and the solutions recommended here should be applicable to those settings as well.

\subsection{Mixed-Ability Classes}

Over $83 \%$ of the teachers surveyed at PSU reported the problem of students with different levels of English proficiency in the same class. Even though the majority of Thai students were assessed at the A2 level based on the Cambridge Quick Placement Test, which is a paper test, based on our observations in many classes the students' actual oral proficiency apparently ranged from the beginner's to the intermediate level. Having students of mixed ability may lead to boredom of higher proficiency students and makes it difficult to arrange communication activities (Likitrattanaporn, 2014). At PSU, students at all faculties take both mandatory and elective oral English communication courses at the Faculty of Liberal Arts. This leads to students with higher proficiency, coming from faculties where admission standards are usually high (e.g., agro-industry, dentistry, medicine, pharmacy, law, nursing) being mixed with students of lower proficiency.

One obvious solution is to employ a placement test so that each class section contains students of the same or similar proficiency level. Another feasible solution is to place students in elective oral communication classes based on their final grade in such mandatory fundamental listening and speaking courses as 890-101 Fundamental English Listening and Speaking. Finally, consideration should be given to having more levels of elective English oral communication classes (currently there is only one level) so students with higher levels of proficiency could elect to take more challenging courses such as those targeting debating and critical thinking skills.

The Serbian context as presented in this paper is a result of the implementation of such changes; namely, until 2007 students who took English as an elective course at UNS were not grouped according to their level of English but were taking mixed-ability English classes. In 2007, a placement test was implemented for the first time, when it was assessed for validity (Radić-Bojanić, 2008, 2009), and the present-day situation, where students are streamlined after the CEFR levels, illustrates how homogeneous groups of students of approximately the same levels of language proficiency lead to success in all areas, oral competence included.

\subsection{Class Sizes Too Big}

Fifty percent of the teacher respondents reported class sizes that had 40 or more students. A class size that is too big gives students insufficient speaking practice and limits the ability of the teacher to give students individual attention. It also makes it more difficult for the teacher to navigate the classroom to arrange and monitor communicative activities (Likitrattanaporn, 2014). At the Faculty of Liberal Arts, some classrooms can accommodate as many as 150 students. Additionally, the demand to take oral English communication courses increases annually, leading to pressure to increase class size.

For an effective oral English communication class there needs to be a rigorously maintained upper enrollment limit, say 40 students for instance. Given that demand to take elective oral English communication courses exceeds available teacher resources, higher level proficiency students could be relegated to more advanced courses, taking the pressure off class size for A2 learners. 


\subsection{Overemphasis on Group Work}

All the Thai teachers surveyed reported that their teaching methods involved pair work, followed by group work $(91.7 \%)$ and individual work (58.3\%). When it came to assessment, all the teachers used role plays to assess their students (a requirement) as well as mid-term and final exams. The Thai students' perspectives apparently supported their teachers' reported teaching methods. The Thais were however least comfortable with individual work such as volunteering and answering questions. In this respect, they appeared less independent than the Serbians. As reported in Bruner et al. (2014), Thai learning styles were affected by a group-oriented Thai culture in which cooperative and group work is preferred over individual learning and individual work. They also excelled more in group work because of their collectivist cultural orientation. By contrast, the Serbians have an individualistic cultural identity, enabling them to excel in individual tasks including individual assignments, asking and answering questions and individual assessment.

Most research today supports a high degree of collaborative or cooperative learning in the EFL classroom, which involves emphasis on pair and group work that is consistent with the CLT approach (see Trong Tuan, 2010).But academic success at the tertiary level leading to a successful post-graduate career is in large part based on individual achievement with a reliance on university admission tests, proficiency tests and examinations for assessment, all of which measure English proficiency. A case in point is that while all graduate students at PSU must pass the in-house Test of English Proficiency (TEP) and score at least $45 \%$ in order to graduate, the undergraduates are now also required to take an in-house test to assess their English proficiency during their third year of study before graduation.

Reportedly, similar to those of other Asian cultures, Thai students often shied away from individual communicative tasks such as volunteering, asking and answering questions and expressing opinions for fear of "losing face". Since this can hinder the development of their oral communication skills, teachers should play an active role in building the rapport between class participants and creating an environment in which learner anxiety can be minimized (Burden, 2004). At the same time, they should try to strike a balance between cooperative and individual tasks, so their students will not fail miserably with the latter due to a lack of experience in confronting and overcoming their anxiety and thereby acquiring confidence to use the language spontaneously.

The imbalance of group work and individual work for A2 learners can be redressed to an acceptable degree by introducing more individual in-class oral activities such as individual oral presentations and an interview with the teacher as part of the requirements. The latter requirement was recently introduced in the English conversation elective course at PSU Liberal Arts. Students are required individually to speak with their teacher about their family, their personal and academic interests and goals as well as describing a photograph.

\subsection{Unrealistic Dialogues in Role-Play Contradicting CLT}

Closely related to the overreliance on group work is the over-application of scripted role plays. Since one of the key features of CLT is to expose the learners to genuine, authentic use of the target language in a meaningful interaction as frequently as possible, in-class oral activities such as non-scripted role-plays are more preferable than scripted ones. However, based on our observations, the role-play as applied in all the oral communication classes at PSU are of the scripted type in which the students were allowed to prepare and rehearse their conversation scripts in advance before the actual performance. This is apparently counterproductive given the spontaneous nature of ordinary conversation they need to master. In genuine conversation we rarely plan ahead what we say in real conversation, leaving it to the moment-by-moment interaction contingency (Herazo Rivera, 2010).

It is a better learning experience for students to produce utterances in real time rather than ask questions they have rehearsed in a parrot-like fashion. In a non-scripted role play students ask questions based on their actual knowledge of the language or gained through the role play activity by interacting spontaneously with other students and thereby achieving the goal of developing spontaneous oral production (Ellis, 2003, cited in Herazo Rivera, 2010). Additionally, even though both scripted and non-scripted role-play activities can help learners to improve their English speaking performance, non-scripted role-plays have been proven to contribute to the improvement of the learners' discrete oral performance and conversation skills as appear in naturally-occurring conversation to a more significant degree than scripted ones for both high and low proficiency learners. Non-scripted role-play activities better contribute to the holistic improvement in oral English performance of the Thai EFL learners than scripted ones (Phuetphon, Chayanuvat, \& Sitthitikul, 2012; Rodpradit \& Sinwongsuwat, 2012; Sinwongsuwat, 2011). The improvement was particularly evident in such practices as turn-taking and sequence organizing, overlap, reciprocal greeting, third-turn assessment, repair, and the use of turn-holding 
devices (Naksevee \& Sinwongsuwat, in press).

\section{Concluding Remarks}

The study focused on current EFL teaching practices in the oral English communication classroom based on the key players, teachers and A2 level university students in starkly contrasting cultural settings, namely Prince of Songkla University(PSU), Thailand and University of Novi Sad (UNS), Serbia. The rationale of the study and overall objectives were to identify current practices from the perspectives of teachers and students, identify key problems faced by teachers and students committed to Communicative Language Teaching (CLT) to improve oral English communication, and make some practical recommendations to improve classroom practices in an attempt to help A2 students in Thailand at the university level move beyond elementary level proficiency.

The main findings were that oral English communication classes at PSU continue to employ the CLT approach and that this resulted in the majority of Thai A2 students frequently undertaking group activities at the expense of individual and teacher-focused tasks. Moreover, students spent a great deal of time preparing and performing unrealistic scripted role plays. The Thai students, in light of the apparent higher proficiency of the Serbian students, need to work at acquiring more independent skills, to be proactive and to use English spontaneously. Both teachers and students encountered difficulties with mixed ability classes and classes that had too many students to be conducive to oral English communication. Practical recommendations included placement tests, a range of more advanced elective courses, restricted class size, an appropriate balance between group and individual communicative tasks to suit A2 learners, and adding non-scripted role plays to the syllabus. Further research should investigate long-term effects of the implementation of such measures and principles. In addition, Thai teachers should emphasize the importance of out-of-class English language learning in order to raise the students' awareness of the variety of possibilities for incidental language learning through the media (the internet, TV, music, films, etc.). This will, in fact, provide authentic language contexts in which students could first witness the application of all the principles they had been taught in class and then could themselves try to use English independently, without scripts or teachers, which will definitely be an illustration of authentic language application they will be required to partake after their graduation in their future work place.

\section{Acknowledgments}

This paper emanates from the research project L1A 560297S, "Comparative study of approaches to the development of oral English communication skills adopted by universities in EFL contexts," funded by Prince of Songkla University, Hat Yai Campus, Thailand. The authors acknowledge the input of other project members: Yaruingam P. Shimray, Jagoda Topalov, Viktoriia Krombholc, Maja Bjelica and Ana Halas. Special thanks to Assoc. Prof. Dr. Adisa Teo, Dean of the Facuty of Liberal Arts, as well as Professor Dr. Ivana Zivancevic-Sekerus, Vice-Dean for International Relations and Science, Faculty of Philosophy, University of Novi Sad, Serbia.

\section{References}

Asassfeh, S., Khwaileh, F., Al-shaboul, Y., \& Alshboul, S. (2012). Communicative language teaching in an EFL context: Learners' attitudes and perceived implementation. Journal of Language Teaching and Research, 3, 525-535.

Baker, W. (2009). The cultures of English as a lingua franca. TESOL Quarterly, 43(4), 567-592.

Bell, K. (2011). How ESL and EFL classrooms differ. Retrieved January 1, 2012, from http://oupeltglobalblog.com/2011/.../how-esl-and-efl-classrooms

Bruner, D. A., Sinwongsuwat, K., \& Shimray, Y. P. (2014). Thai-Serbian A2 university EFL learners' perspectives on learning and teaching oral English communication skills. In P. Subphadoongchone (Ed.), the 34th Thailand TESOL International Conference Proceedings 2014 (pp. 13-34). Chiang Mai: TESOL Thailand.

Burden, P. (2004). The teacher as facilitator: Reducing anxiety in the EFL university classroom. JALT Hokkaido Journal, 8, 3-18.

Burnaby, B., \& Sun, Y. (1989). Chinese teachers' views of Western language teaching: Context informs paradigms. TESOL Quarterly, 23, 219-238.

Byrne, M. (2010). Strong English language skills essential to capitalize on increasing foreign investment in Thailand. Retrieved January 1, 2012, from http://english-click.com/strong-english-language-skills-essentialto-capitalize-on-increasing-foreign-investment-in-thailand/

Cheewakaroon, R. (2011). Teaching change in response to Thai tertiary English language teaching reform (Ph.D. 
thesis, Faculty of Education, University of Wollongong). Retrieved from http://ro.uow.edu.au/cgi/viewcontent.cgi?article=4393\&context=theses

Crystal, D. (2013). English as a global language (2nd ed.). Cambridge, England: Cambridge University Press.

Darasawang, P. (2007). English language teaching and education in Thailand: A decade of change. In D. Prescott (Ed.), English in Southeast Asia: Varieties, literacies and literatures (pp. 187-204). Newcastle, England: Cambridge Scholars Publishing.

Education First. (2012). The EF EPI 2012 Report. Retrieved Aug 23, 2013, from http://www.ef.nl/_/ / /media/ efcom/epi/2012/full_reports/ef-epi-2012-report-master-lr-2

Foley, J. (2005). English in Thailand. RELC Journal, 36(2), 223-234.

Herazo Rivera, J. (2010). Authentic oral interaction in the EFL Class: What it means, what it does not. Profile Issues in Teachers' Professional Development, 12(1).

Kachru, B. (1985). Standards, codification and sociolinguistic realism: The English language in the outer circle. In R. Quirk, \& H. G. Widdowson (Eds.), English in the world: Teaching and learning the language and literature (pp. 11-30). Cambridge, England: Cambridge University Press.

Kessler, M. (2003). Equal opportunity and diversity: The handbook for teachers of English. Retrieved January 1, 2012, from http://www.britishcouncil.org/eod_handbook.pdf

Khamkien, A. (2010) Teaching English speaking skills and English speaking tests in the Thai context: A reflection from Thai perspective. English Language Teaching, 3, 184-190.

Laksanavisit, J. (2009). Proclamation of 2009 the year of Thai higher education quality enhancement: Quality graduates for sustainable development. The National Conference. July 2-3, 2009. The Impact Convention Centre, Impact Areana, Muang Thong Thani. Retrieved January 10, 2012, from http://inter.mua.go.th/main2/article.php?id=18

Likitrattanaporn, W. (2014). Teaching phonological accuracy and communicative fluency at Thai secondary schools. English Language Teaching, 7(2).

Littlewood, W. (2004). The task-based approach: Some questions and suggestions. English Language Teaching Journal, 58(4).

McDonough, K. (2004). Learner-learner interaction during pair and small group activities in a Thai EFL context. System, 32(2), 207-224. http://dx.doi.org/10.1016/j.system.2004.01.003

Phuetphon, P., Chayanuvat, A., \& Sitthitikul, P. (2012). Using unscripted role play to improve speaking ability of Thai EFL students. Proceedings-Teaching Techniques-006 4th International Conference on Humanities and Social Sciences, April 21st, 2012 Faculty of Liberal Arts, Prince of Songkla University, Hatyai, Thailand.

Prapphal, K. (2001). Globalization through distance education via Inter- and Intranet pedagogy. PASAA, 31, 75-81.

Radić-Bojanić, B. (2008). Validity of placement tests in ELT: A case study. In K. Rasulić, \& I. T. Milošević (Eds.), English Language and Literature Studies: Structures Across Cultures Conference Proceedings (pp. 631-640). Beograd: Filološki fakultet.

Radić-Bojanić, B. (2009). Korelacija dijagnostičkog testa jezičke kompetencije i uspeha na ispitu. In J. Vučo (Ed.), Evaluacija u nastavi jezika i književnosti (pp. 145-154). Nikšić: Filozofski fakultet.

Rao, Z. (2002). Chinese students' perceptions of communicative and non-communicative activities in EFL classroom. System, 30, 85-105.

Rodpradit, S., \& Sinwongsuwat, K. (2012). Using scripted and non-scripted role plays to improve English speaking performance of hotel engineering staff. APHEIT Journal, 18(1), 17-25.

Richards, J. C., \& Bohlke, D. (2012). Speak Now 3: Communicate with Confidence (Teacher's Book). Oxford, UK: Oxford University Press.

Saengboon, S. (2002). Beliefs of Thai EFL teachers about communicative language teaching (Unpublished doctoral dissertation). Indiana University, Bloomington USA.

Saraithong, W. (2013). The economic perspective of labor's English language proficiency in the AEC era. WEI International Academic Conference Proceedings, January 14-16, 2013, Antalya, Turkey. Retrieved January 1, 2012, from http://www.westeastinstitute.com/.../ANT-335-Wuthiya-SARAI 
Sinwongsuwat, K. (2012). Rethinking assessment of Thai EFL learners' speaking skills. Language Testing in Asia, 75-85.

Stempleski, S., \& Robertson, E. (2007). Talk Time: English Conversation (Teacher's Book 2). Oxford, UK: Oxford University Press.

Thongprasert, N. (2008). Classroom environments: A case study of Thai students in Thai and Australian universities. Proceedings of the EDU-COM 2008 International Conference Sustainability in Higher Education: Directions for change; Edith Cowan University, Perth, Western Australia, November 19-21, 2008.

Trong Tuan, L. (2010). Infusing cooperative learning into an EFL class. English Language Teaching, 3(2). http://dx.doi.org/10.5539/elt.v3n2p64

University of Cambridge-Local Examinations Syndicate. (2001). Quick placement test: Paper and pen test: User manual. UK: Oxford University Press.

WhereisThailand.info. (2012, July 25). Where is Thailand in English Proficiency? Retrieved August 17, 2013, from http://whereisthailand.info/2012/07/english-proficiency/

Whong, M. (2011). Language teaching: Linguistic theory in practice. Edinburgh, Edinburgh University Press.

\section{Appendix}

\section{Information on the student and teacher questionnaires used}

As indicated in the methodology section 2 of this paper, the questionnaires given were designed to adduce a comprehensive view of oral English language teaching and learning from both students and teachers' perspectives, with the focus on issues often encountered by and of concern to EFL language educators.

With a Cronbach's alpha reliability coefficient of .918, the questionnaire for students consisted of two main parts. The first part had two subsections. Dealing with participants' demographic data, the first subsection aimed at eliciting their background and learning experience which were assumed to affect their perspectives on language learning and teaching. The second subsection consisted of questionnaire items comprised of statements with the Likert scale. Students were asked to respond to each statement by indicating whether they strongly disagreed (1), disagreed (2), were neutral (3), agreed (4), and strongly agreed (5). The statements were divided into six categories, namely students' perspectives on teaching methods, teacher factors (about the teacher's personality and style), learning styles, learners' motivation, learning difficulties and teacher-learner communication.

For teaching methods, the statements included whether the course was interesting, provided enough authentic examples of spoken English and communicative tasks for real-life communication, the balance between accuracy and fluency-focused activities, the appropriateness of the frequency of the teacher speaking English/Thai, awareness of world Englishes, opportunities to speak English in class, the requirement of group work, appropriateness and accuracy of assessment, freedom to volunteer answers and freedom for self-directed activities.

Regarding teaching factors, items included teachers' style and feedback, pronunciation, and attention to students' individual needs. Concerning learning styles, the focus was on student participation, group activities, self-study, and use of English outside the class. Learners' motivation dealt with both instrumental and integrative motivation, including whether students wanted to learn English for a better job, better grades, to satisfy parents, to travel abroad, because English is a global language, to be able to speak to native speakers and to learn more about other cultures and access English media.

Statements on learning difficulties focused on class size, equipment, study facilities at home, time to study, family and peer support and access to English media and private classes. Finally, teacher-learner communication centered on communication only in class, only about course-related matters, and/or communication with the teacher about anything.

The second part of the student questionnaire canvassed students' perceptions of the English speaking course syllabus, teaching methods, class facilities, and schedule. Students were asked to check items that apply to each topic and rank them in order of frequency.

Similar to the questionnaire for students, the teacher questionnaire has two parts, of which one elicited teachers' background and the other was similar to the second part of the student questionnaire. Validated with a Cronbach's alpha reliability coefficient of .874 , the teacher questionnaire was used to elicit teachers' perspectives 
on the course syllabus, class activities, assessment, teaching methods, class size, facilities and arrangement, class schedule, and teaching difficulties. Statements about the syllabus involved the use of commercial or in-house course books, the Internet and other materials. Class activities statements adduced information about teachers involving students in pair and group work, class discussions, peer feedback, asking and answering questions and volunteering. It also addressed teacher priorities related to tasks concerning real-world uses of spoken English, accuracy, meaning and fluency focused activities, monitoring students' progress and providing feedback and strategies making oral English communication learning manageable.

The category of assessment canvassed assessment types often used, including oral presentations, grammar, vocabulary and reading comprehension tests and term exams. Teaching methods elicited which methods were often used, including lectures, modeling, individual, pair and group work, teacher and peer feedback, whole-class discussions, structure of the lesson (eg. instructions, wrap-up), and method of correcting students. The statements about class size, facilities and arrangements sought to obtain information about the average class size, adequacy of equipment and arrangement of desks in the class.

The class schedule items focused on class-start time and teacher preferences. Finally, teaching difficulties concern problems when teaching oral English such as class sizes, mixed ability classes and student motivation.

\section{Copyrights}

Copyright for this article is retained by the author(s), with first publication rights granted to the journal.

This is an open-access article distributed under the terms and conditions of the Creative Commons Attribution license (http://creativecommons.org/licenses/by/3.0/). 